\title{
The Estimated Number of Occupational Diseases and Work-Related Diseases in Turkey
}

\author{
Defne KalaycI*, , , $\mathrm{MD}]$ \\ ORCID:0000-0003-0206-510X \\ Mehmet Erdem Alagüney ${ }^{2},[\mathrm{MD}]$ \\ ORCID:0000-0001-7380-9404 \\ Ali Naci Yıldız ${ }^{3},[\mathrm{MD}]$ \\ ORCID:0000-0001-8148-4710
}

${ }^{1}$ Hacettepe University, Faculty of Medicine, Department of Public Health, Education Protocol of Occupational Medicine, Ankara, MD ${ }^{2}$ Eskişehir Yunus Emre State Hospital, Department of Occupational Medicine, Eskişehir. ${ }^{3}$ Hacettepe University, Faculty of Medicine, Department of Public Health, Ankara.

* Corresponding Author :Defne Kalaycı Hacettepe University Faculty of Medicine Outpatient Clinic of Occupational Medicine, Sıhhıye-Altındağ/ANKARA

E-mail: defnekalayci@hacettepe.edu.tr Phone: 0312- 3053426

\section{we) ABSTRACT Cen}

Objective: The number of occupational diseases are lower than expected in Turkey. We aimed to estimate the number of occupational diseases, work-related diseases, and deaths due to occupational exposures by using international estimations of attribution of workplace in this descriptive study. Materials and Methods: The attributable fraction values to occupation for selected diseases and deaths were compiled from the literature. Information on these diseases and deaths in Turkey was obtained from national burden of disease studies and statistics of Turkish Statistical Institute. The estimated number of occupational diseases, work-related diseases and deaths due to occupational exposures were calculated by using the number of diseases and deaths in Turkey and by the fraction of occupational exposures by using literature.

Results: Based on the data of national burden of disease studies in Turkey; 321,868 musculoskeletal disorders, 79,232 to 95,845 circulatory system diseases, 38,994 to 56,992 chronic obstructive pulmonary diseases, 14,563 to 19,858 asthma cases, 29,550 hearing losses, and 4,902 to 16,341 cancer cases are estimated to be work-related. According to the Turkish Statistical Institute data, the number of deaths due to occupational causes was estimated to be 8,143 in circulatory system diseases; 1,913 in malignant tumors; and 2,130 in respiratory system diseases. However, the lowest and the highest number of occupational diseases announced by the Social Security Institution between 2007 and 2016 is 371 and 1,208, respectively.

Conclusion: There are deficiencies in the diagnosis and reporting of occupational diseases. In order to plan and implement preventive actions, data should be reported in a large scale and reliable manner.

Keywords: Attributable fraction, burden of disease, occupational diseases

Received: 30 April 2019, Accepted: 09 September 2019,

Published online: 30 September 2019

\section{INTRODUCTION}

Occupational diseases occur with the influence of factors found in the workplace. There is a unique and strong relationship between occupation and disease [1]. Although occupational diseases are preventable, they remain an important public health problem. According to the International Labour Organization (ILO) estimations, approximately 2.4 million people die of work-related illnesses, annually [2]. Leigh et al. estimated absolute morbidity and mortality due to occupational factors using all available published data, which showed that $2.7 \%$ of all global DALYs (Disability-Adjusted Life Years) are due to occupational factors [3]. These diseases also cause an economic burden because of their high costs. In 2007, the estimated burden of occupational illnesses is 58 billion dollars [4].

Work-related diseases, have multiple causes and workplace-related factors are involved in the etiology of the disease along with the other factors [1]. A 2017 study estimated 2.4 million of 2.78 million deaths are attributed to work [2]. These numbers are higher when compared to those published in 2012: The number of estimated work-related deaths were 2.3 million in 2012, of which two million were caused by work-related diseases. Work-related cancer was the primary cause of death (32\%) and followed -in decreasing order- by work-related circulatory system diseases (23\%), occupational accidents 
(18\%) and communicable diseases (17\%) [5]. In 2017, with the inclusion of Chronic Obstructive Pulmonary Disease (COPD) in the list, the toll of respiratory system diseases increased (17\%) and became one of the top three morbidities, following circulatory system diseases (31\%) and malignant neoplasms (26\%). They were followed by occupational injuries (14\%) and communicable diseases (9\%) [2]. The last two causes, however, were less common in the developed countries [5].

The annual number of occupational diseases announced by the Social Security Institution (SSI) Turkey- the only official statistical data source for the number of occupational diseases in Turkeyranges between 371 and 1,208, for years 2007 through 2016. The number of deaths due to occupational diseases for the same period ranges from 0 to 10 [6]. State university hospitals, education and research hospitals and occupational diseases hospitals are all authorized to diagnose occupational diseases in Turkey, according to relevant regulation. However, the final decision on compensation for occupational diseases is given by the SSI [7]. Number of insured patients receiving continuous incapacity income (i.e., those who lost at least $10 \%$ of their earning power) is annually published in occupational diseases statistics.

Data from SSI reveal that there were $21,131,838$ active insured employees in 2016 [8]. Despite variability between countries, 4 to 12 occupational diseases are expected per 1000 workers, anually [9]. Accordingly, 84,527 to 253,582 occupational diseases would have been detected in Turkey in 2016. However, only 597 patients received continuous incapacity income in 2016. No deaths from occupational diseases were detected in this period [6]. The number of employees under $10 \%$ decrease in earning power is not published, even they have an occupational disease. The distribution of occupational diseases in Turkey with data of SSI in 2016 was presented in Table 1. Apparently, occupational diseases do not take place properly in statistics.

Obviously, the real number of occupational diseases is one of the main requirements for planning and implementing appropriate preventive activities. If these numbers can not be determined; employees

Table 1. Number of occupational diseases reported by SSI (2016) [5]

\begin{tabular}{|c|c|c|}
\hline Occupational Disease & Number & Percent \\
\hline Respiratory system diseases & 216 & 36.1 \\
\hline Nervous system diseases & 22 & 3.6 \\
\hline Musculoskeletal diseases & 21 & 3.5 \\
\hline Ear and mastoid diseases & 6 & 1.0 \\
\hline Skin and subcutaneous tissue diseases & 5 & 0.8 \\
\hline Diseases of blood and blood-forming organs and some disorders of immune system & 5 & 0.8 \\
\hline Malignant and Neoplasms & 2 & 0.3 \\
\hline Eye and adnexa diseases & 2 & 0.3 \\
\hline Genitourinary system diseases & 1 & 0.1 \\
\hline Some Infectious and Parasitic Diseases & 1 & 0.1 \\
\hline Those who are not on the list of occupational diseases & 141 & 23.6 \\
\hline Diagnosis after the end of insurance & 175 & 29.3 \\
\hline TOTAL & 597 & 100.0 \\
\hline
\end{tabular}


can not obtain their rights, the importance of the issue can not be emphasized and the attention of the policy makers can not be attracted. In this paper, we aimed to reach robust estimates of the number of occupational diseases, work-related diseases and deaths due to occupational diseases.

\section{MATERIALS AND METHODS}

Information on diseases in Turkey was obtained from three sources: 2004 Turkey Burden of Disease study of Ministry of Health [10], 2016 Health Statistics Yearbook [11] and 2017 Turkey Cancer Statistics of Public Health Agency [12]. Data on rate and causes of death were taken from statistics of Turkish Statistical Institute (TSI) 2016 [13]. The number of occupational diseases and deaths due to occupational diseases were taken from SSI statistics [6].

The attributable fraction of occupation for selected diseases and deaths were compiled from literature and these values were used to estimate the number of occupational diseases in Turkey.

The study was prepared in accordance with the Declaration of Helsinki. Since the study included publicly available literature review, no patient consent was obtained.

\section{RESULTS}

Results are presented under subheadings of selected diseases, cancers alone and causes of death.

Selected Diseases: Musculoskeletal disorders, circulatory system diseases, COPD, asthma, hearing loss and cancers are common diseases in Turkey based on the National Burden of Disease Study [10]. The attributable fraction to occupation for musculoskeletal diseases was estimated as $37 \%$ in the study of World Health Organization (WHO) [14]. According to the Health Statistics Yearbook Turkey (2016), 869,916 musculoskeletal system diseases were diagnosed in our country [11]. Therefore, 321,868 musculoskeletal disorders could be work-related.

According to Takala's research, the attributable fraction of occupation for circulatory system diseases was $12.4 \%$ [5]. 638,968 circulatory system diseases were identified in Turkey Burden of Disease Study (2004) [10]. From this data, it was calculated that 79,232 circulatory system diseases in our country could be work-related.
In various studies, the attributable fraction of occupation for COPD was $13 \%$ to $15-19 \%[5,15]$. It was calculated that 38,994 to 56,992 of the 299,958 patients diagnosed with COPD in Turkey Burden of Disease Study (2004) could be occupational [10].

In literature, the attributable fraction of occupation in all asthma cases was $11 \%$ to $15 \%[14,16]$. It was calculated that 14,563 to 19,858 of the 132,392 patients diagnosed with asthma in Turkey Burden of Disease Study (2004) could be occupational [10].

In literature, it was estimated that $16 \%$ of hearing loss cases were occupational [14]. It was calculated that 29,550 of the 184,692 patients diagnosed with hearing loss in Turkey Burden of Disease Study (2004) could be occupational [10].

The attributable fraction of occupation for these selected diseases, number of diseases based on studies in Turkey, the expected estimated number of occupational diseases and work-related diseases were given in Table 2.

Cancers: In a review on global burden of disease estimates of occupational exposure, the attributable fraction for cancer was 3-10\% [17]. According to Turkey Cancer Statistics (2017) 163,417 new cancer cases were diagnosed in our country [12]. According to this, we calculated 4,902 to 16,341 cancer cases which is expected to be occupational (Table 2).

According to WHO data, attributable fraction to occupation for lung cancer was 9\% [14]. 23,833 new cases were reported for trachea, bronchus and lung cancer, as being the most common types of cancer in 2014 [12]. 29,314 new lung cancer cases were estimated for each year by "Turkey's lung cancer map" project of Turkish Thoracic Society in 2009 [18]. We calculated that 2,144 to 2,638 lung cancer cases could be occupational.

Causes of death: The attributable fraction of work-related exposures to the disease mortality and the estimated number of deaths from work-related diseases or occupational diseases are calculated according to the cause of death statistics of TSI (2016), as presented in Table 3. The attributable fraction of work-related mortality of circulatory system diseases was reported as $6.3 \%$ by Steenland et al. [19]; and it was calculated as $14.4 \%$ for men and $6.7 \%$ for women in the study of Nurminen and Karjalainen [20]. Circulatory system diseases -causing 162,876 deaths- were in first place in death statistics [13]. It was calculated that at least 10,261 of these should 
Table 2. The attributable fraction for diseases due to occupation, number of diseases based on studies in Turkey, the expected estimated number of occupational and work-related diseases

\begin{tabular}{|c|c|c|c|c|c|c|c|c|}
\hline \multirow{3}{*}{ Disease } & & & \multicolumn{6}{|c|}{ Attributable fraction } \\
\hline & \multicolumn{2}{|c|}{ Turkey } & \multicolumn{3}{|c|}{ Lowest } & \multicolumn{3}{|c|}{ Highest } \\
\hline & Number & $\begin{array}{l}\text { Reference } \\
\text { number }\end{array}$ & Percent & $\begin{array}{c}\text { Estimated } \\
\text { Number }\end{array}$ & $\begin{array}{l}\text { Reference } \\
\text { nember }\end{array}$ & Percent & $\begin{array}{l}\text { Estimated } \\
\text { Number }\end{array}$ & $\begin{array}{c}\text { Reference } \\
\text { number }\end{array}$ \\
\hline COPD & 299,958 & 9 & 13 & 38,994 & 13 & $15-19$ & $\begin{array}{l}44,993 \\
56,992\end{array}$ & 14 \\
\hline Asthma & 132,392 & 9 & 11 & 14,563 & 13 & 15 & 19,858 & 15 \\
\hline $\begin{array}{l}\text { Circulatory system } \\
\text { diseases }\end{array}$ & 638,968 & 9 & 12.4 & 79,232 & 4 & 15 & 95,845 & 25 \\
\hline $\begin{array}{l}\text { Musculoskeletal sys- } \\
\text { tem diseases }\end{array}$ & 869,916 & 10 & 37 & 321,868 & 13 & -- & -- & -- \\
\hline Hearing loss & 184,692 & 9 & 16 & 29,550 & 13 & -- & -- & -- \\
\hline Contact dermatitis & -- & -- & 14 & -- & 25 & -- & -- & -- \\
\hline Hepatitis B & 6,600 & 26 & 4 & 264 & 25 & -- & -- & -- \\
\hline Tuberculosis & 13,378 & 27 & 5 & 668 & 25 & -- & -- & -- \\
\hline Cancer & 163,417 & 11 & 3 & 4,902 & 16 & 10 & 16,341 & 16 \\
\hline Lung & 23,833 & 11 & 9 & 2,144 & 13 & 29 & 6,911 & 28 \\
\hline Nasopharynx & 621 & 11 & 1.06 & 6 & 29 & 24 & 149 & 28 \\
\hline Melanoma & 1,166 & 11 & 2 & 23 & 16 & 4.3 & 50 & 28 \\
\hline Bladder & 8,606 & 11 & 2.1 & 180 & 29 & 14.2 & 1,222 & 28 \\
\hline Leukemia & 232 & 11 & 2 & 4 & 13 & 18.5 & 42 & 28 \\
\hline Stomach & 8,090 & 11 & 2 & 161 & 30 & 10.3 & 833 & 28 \\
\hline Mesothelioma & 544 & 11 & 75 & 408 & 29 & 90 & 489 & 28 \\
\hline TOTAL & & & & 490,041 & & & 541,386 & \\
\hline
\end{tabular}

be work-related.

The attributable fraction for work-related mortality of malignant tumors was reported as $8 \%$ in men, $1.5 \%$ in women by Rushton et al. [5, 21]; 3.3-7.3\% in men, $0.8-1.0 \%$ in women by Steenland et al. [19]. In Turkey, a total of 78,931 people, of which 51,296 were male, lost their lives due to malignant tumors [13]. Based on this data, number of deaths due to occupational malignant tumors in our country were calculated as at least 1,692 in men and 221 in women. In the study of Nurminen and Karjalainen, the attributable fraction for work-related mortality of respiratory diseases was reported as $6.8 \%$ in men and $1.1 \%$ in women [20]. In Turkey, respiratory system diseases caused 48,532 deaths, of which 28,025 were male [13]. It is calculated that 1,905 men and 225 women are expected to lose their lives because of work-related respiratory diseases.

In Nurminen and Karjalainen's studies, the attributable fraction for work-related mortality of all deaths in Finnish population was calculated to be $6.7 \%$ (10.2\% for male; $2.1 \%$ for female) [20]. In Turkey, it was calculated that 22,588 of the 221,460 total male deaths, 3,932 of the 187,268 total female deaths could be due to occupational diseases or work-related diseases [13]. 


\section{DISCUSSION}

There are important problems in both diagnosis and reporting of occupational and work-related diseases in our country. Failure to detect occupational diseases, which are preventable, is of great importance for proper management of the rights and obligations of employees and employers, to reduce relevant economic

Table 3. The attributable fraction for work-related mortality of diseases; the estimated number of deaths from work-related disease or occupational disease calculated according to cause of death statistics of TSI (2016) [12]

\begin{tabular}{|c|c|c|c|c|c|c|c|}
\hline \multirow[t]{2}{*}{ Cause of death } & \multicolumn{2}{|c|}{$\begin{array}{c}\text { Turkey } \\
\text { Total Number }\end{array}$} & \multicolumn{3}{|c|}{ Attributable fraction (Percent) } & \multicolumn{2}{|c|}{$\begin{array}{c}\text { Turkey } \\
\text { Estimated Number }\end{array}$} \\
\hline & Male & Female & Male & Female & $\begin{array}{l}\text { Reference } \\
\text { number }\end{array}$ & Male & Female \\
\hline Cancer & 51,296 & 27,635 & 13.8 & 2.2 & 4 & 7,078 & 607 \\
\hline Lung & 20,815 & 3,743 & 15 & 5 & 4 & 3,122 & 187 \\
\hline Malignant & 296 & 187 & 4.3 & 0.4 & 18 & 12 & 1 \\
\hline Melanoma Bladder & 1,795 & 330 & 10 & 5 & 4 & 179 & 16 \\
\hline Lymphoid and Hematopoietic & 3,703 & 2,681 & 10 & 5 & 4 & 370 & 134 \\
\hline Colon & 3,335 & 2,407 & 5.6 & 0.0 & 18 & 186 & -- \\
\hline Breast & 86 & 3,936 & -- & 1.7 & 18 & -- & 66 \\
\hline COPD & 16,171 & 8,697 & 14 & 3.8 & 4 & 2,263 & 330 \\
\hline Asthma & 683 & 1,212 & 17.8 & 18.4 & 4 & 121 & 223 \\
\hline Communicable diseases & 4,395 & 4,047 & 4.8 & 32.5 & 4 & 210 & 1,315 \\
\hline Circulatory system diseases & 80,605 & 82,271 & 14.4 & 6.7 & 4 & 11,607 & 5,512 \\
\hline Chronic kidney disease & 6,565 & 6,725 & $8.2-14.5$ & -- & 31 & $538-951$ & -- \\
\hline Digestive system diseases & 5,231 & 4,814 & 2.3 & 1.5 & 18 & 120 & 72 \\
\hline Pneumonia & 8,499 & 8,130 & 1.4 & 0.3 & 18 & 118 & 24 \\
\hline Alzheimer's disease & 5,114 & 8,000 & 3.4 & 1.8 & 18 & 173 & 144 \\
\hline TOTAL & & & & & & $\begin{array}{r}22,228 \\
+22,641\end{array}$ & 8,227 \\
\hline
\end{tabular}


losses and their overall burden on health services.

Under-reporting of occupational diseases is an important issue in Turkey, similar to other countries [22]. Level of development of countries, the rights granted to employees, and the level of organization of employees are positively associated with presence of proper morbidity and mortality estimates for countries.

Discussion section is presented under subheadings of selected diseases, cancers alone and causes of death.

Selected Diseases: The total of estimated number for work-related diseases is approximately 500,000 for musculoskeletal diseases, circulatory system diseases, and COPD [10, 11]. However, the total number of compensated occupational diseases repoted by SSI in 2016 was 597 [6]. In this evaluation, although a significant part of estimated numbers was composed of work-related diseases, it should be remembered that occupational diseases were also included among them. Moreover, the estimated number of occupational hearing loss was 29,550, whereas for SSI in 2016, the number was only 6 [6]. Even this difference shows the severity of the problem in reporting rates for such conditions.

According to the results of the Research on Occupational Accidents and Work-Related Health Problems which were designed in the form of a modular questionnaire published by TSI in 2013, 895 (2.1\%) of 43,655 people who have been employed or had worked in the past, experienced a work-related disease in the last 12 months or in previous jobs. It was determined that $24.9 \%$ of those was musculoskeletal problems affecting the back or waist and $20 \%$ had stress disorders, depression and anxiety problems [23]. It is noteworthy that these diseases are occupational diseases detected in developed countries. In the same study, it was reported that $5.8 \%$ of patients with a work-related illness had respiratory disorders; 1 per cent of them had hearing problems [23]. In this study, the scope of health problems related to work was not limited to cases accepted or registered by the authorities, but the patient's perception that his / her illness was caused by work. As a result, it was reported that $2.4 \%$ of men and $1.6 \%$ of women who have been employed or had worked in the past had a work-related disease. [23]. This frequency is above the world statistics.

Cancers: In SSI statistics of Turkey, two cases were reported under the title of malignant neoplasm in 2016 and one case were reported in 2014; no occupational cancer diagnosis was made in 2015 [6].
Whereas, we calculated thousands of cancer cases which is expected to be occupational $[12,17]$. In Britain, where the number of employees is similar, the five leading malignancies in the estimated 13,598 cancer cases attributable to occupational exposure in 2004 were lung cancer (40\%), non-melanoma skin cancer (21\%), breast cancer (14\%), mesothelioma (14\%) and bladder cancer (4\%) [24, 25].

Causes of death: Most recently in 2012 in SSI statistics, 1 occupational disease mortality was reported, and in the following years there was no work-related death case in the lists [6]. It should be taken into account that the distinction between basic, intermediate, and final causes of death may not have been made correctly when assessing mortality statistics. Under-reporting of deaths due to occupational diseases in our country is a serious problem beyond the result of not detecting occupational diseases.

The major limitations of our study are difficulties in accessing the data, scarcity of researches related to this subject, obtaining the comparisons and calculations from different periods, and the number of diseases and number of deaths included all age groups. Different reference years were taken as basis in the available limited resources in our country regarding the burden of disease.

The number of diseases in the main categories included the sum of men and women in all age groups. However, the reality is that there are clusters of certain age and sex in working life.

The attributable fractions compiled from the literature are related to the host factors of the population concerned such as age, gender, genetic structure and environmental factors such as working conditions and working hours. It should be noted that these factors vary between countries, even between regions in the same country. However, this variability was tried to be reduced by calculating the lowest and highest number. In addition, we think that this is an important step in terms of revealing the general perspective of the national burden of occupational diseases.

In order to solve the problem of underreporting of occupational diseases, the problem should be established and accepted by all parties. It is emphasized especially by public institutions and all related parties that occupational diseases are not sufficiently determined. Activities are carried out to determine the real numbers. A protocol was signed 
in 2010 between the Ministry of Labor and Social Security and the Ministry of Health in order to reach more occupational disease diagnosis [26]. With the cooperation of both ministries, "Enhancement of Occupational Disease Detection, Diagnosis and the sensitivity of the Occupational Health and Safety Professional in Turkey" project was carried out in order to increase awareness of health professionals about occupational diseases [27].

Employees, employers and public institutions, as well as academic institutions should engage in activities about awareness, cooperation, coordination, data sharing and research needs of civil society organizations and professional organizations. The need of epidemiological research on this subject is significant. One of the most obvious interventions would be the authorization of all physicians for diagnosis of occupational and work-related diseases and the collection of these data by the Ministry of Health. Insurance institutions such as SSI, should implement insurance transactions in accordance with the legislation, among these diseases.

It should be remembered that beyond all these considerations, the main issue is the prevention of occupational diseases. The results of this study will contribute to the legislative arrangements, plans and practices that will be carried out both in the workplace and throughout the country by putting out the dimensions of the problem. 
[1] Alagüney ME, Yıldız AN. Meslek hastalıkları - tanım ve sıklığı, Yıldız AN, Sandal A, editörler. Meslek hastalıkları işle ilgili hastalıklar (seçilmiş başlıklarda), Ankara: Hacettepe üniversitesi yayını; 2018.s.3-5.

[2] Hämäläinen P, Takala J, Kiat TB. Global estimates of occupational accidents and work-related illnesses 2017. Ministry of Social Affairs and Health Finland: Workplace Safety and Health Institute.

[3] Leigh J, Macaskill P, Kuosma E, et al. Global burden of disease and injury due to occupational factors. Epidemiology (Cambridge, Mass). 1999;10(5):626-31.

[4] Leigh JP. Economic burden of occupational injury and illness in the United States. Milbank Q. 2011; 89(4): 728-772.

[5] Takala J, Hamalainen P, Saarela KL, et al. Global estimates of the burden of injury and illness at work in 2012. Journal of occupational and environmental hygiene. 2014;11(5):326-37.

[6] SGK. İş Kazası ve Meslek Hastalıkları İstatistikleri. Erişim: 06 Ocak 2019, https://tuisag.com/yillik-is-kazalari-istatistikleri/

[7] Çalışma Gücü Ve Meslekte Kazanma Gücü Kaybı Oranı Tespit İşlemleri Yönetmeliği Resmi Gazete, 27021, 11 Ekim 2008.

[8] SGK. Sosyal Güvenlik Kurumu İstatistik Yıllıkları. Erişim: 21 Mayıs 2018, http://www.sgk.gov.tr/wps/portal/sgk/tr/kurumsal/ istatistik/sgk_istatistik_yilliklari.

[9] Aw T, Gardiner K, Harrington J. Occupational health: Pocket consultant. Oxford: Blackwell Publishing 2007.

[10] Ünüvar N, Mollahaliloğlu S, Yardım N. Türkiye hastalık yükü çalışması 2004. TC Sağlık Bakanlığı, Refık Saydam Hıfzıssıhha Merkezı Başkanlığı, Hıfzıssıhha Mektebi Müdürlüğü 1Basım Ankara: Aydoğdu Ofset Matbaacılık San ve Tic Ltd Şti. 2006:1-56.

[11] T.C Sağlık Bakanlığı. (2017). Sağlık İstatistikleri Yıllığı. Erişim: 21 Mayıs 2018, https://dosyasb.saglik.gov.tr/ Eklenti/13183,sy2016turkcepdf.pdf?0

[12] Türkiye Halk Sağlığı Kurumu. (2017). Türkiye Kanser İstatistikleri. Erişim: 21 Mayıs 2018, https://hsgm.saglik.gov.tr/tr/kanser-istatistikleri/yillar/495-2014-y\%C4\%B1/\%C4\%B1-t\%C3\%BCrkiye-kanser-istatistikleri.htm

[13] TÜiK. (2016). Türkiye İstatistik Kurumu Ölüm Nedeni İstatistikleri. Erişim: 21 Mayıs 2018, http://www.tuik.gov.tr/PreTablo. do?alt_id=1083

[14] Concha-Barrientos M, Nelson DI, Driscoll T, et al. Selected oc cupational risk factors. Comparative quantification of health risks: global and regional burden of disease attributable to selected major risk factors Geneva: World Health Organization. 2004;1651-801.

[15] Kocabaş A. Kronik Obstrüktif Akciğer Hastaliği Epidemiyolojisi Ve Risk Faktörleri. TTD Toraks Cerrahisi Bülteni. 2010;1(2):105-13.

[16] Tan J, Bernstein JA. Occupational asthma: an overview. Current allergy and asthma reports. 2014;14(5):431.

[17] Rushton L. The Global Burden of Occupational Disease. Current environmental health reports. 2017;4(3):340-8.

[18] Türkiye Akciğer Kanseri Derneği. (2016). Akciğer Kanseri Yol Haritası. Erişim: 05 Haziran 2018, http://takd.org.tr/ AkcigerYolHaritasiTRbasimVERSIYONU.pdf

[19] Steenland K, Burnett C, Lalich N, et al. Dying for work: The magnitude of US mortality from selected causes of death associated with occupation. Am. J. Ind. Med. 2003; 43(5):461-482.

[20] Nurminen M, Karjalainen A. Epidemiologic estimate of the proportion of fatalities related to occupational factors in Finland. Scandinavian journal of work, environment \& health. 2001;27(3):161-213.

[21] Rushton, L, Hutchings SJ, Fortunato L, et al. Occupational cancerburden in Great Britain. Br. J. Can. 2012; 107:3-7.

[22] ÇSGB. (2012). Dünyada Ve Ülkemizde Meslek Hastalıkları. Erişim: 21 Mayıs 2018, http://www.hisam.hacettepe.edu.tr/calistaysunum/HavvaRanaGuven.pdf

[23] TÜiK. (2014). İş Kazaları ve İşe Bağlı Sağlık Problemleri. Erişim: 11 Haziran 2018, http://www.tuik.gov.tr/jsp/duyuru/upload/yayinrapor/2013_ISKAZALARI_VE_SAGLIK_PROBLEMLERI_RAPORU. pdf

[24] Hastings D. Annual local area Labour Force Survey 2003/04. Labour Market Trends, 2005;111: 21-32.

[25] Purdue MP, Hutchings SJ, Rushton L, et al. The proportion of cancer attributable to occupational exposures. Annals of epidemiology. 2015;25(3):188-92.

[26] İş Sağlığı Ve Güvenliği Alanında İşbirliği Protokolü . (2010). Erişim: 25 Haziran 2018, file:///C:/Users/Asus/ Downloads/20130920161750_0\%20(1).pdf

[27] ÇSGB Strateji Geliştirme Başkanlığı. Bakanlığımız Ve Bağlıİlgili Kuruluşlarınca Yürütülen Projeler. Erişim: 25 Haziran 2018, https://www.csgb.gov.tr/media/2041/proje_2011.pdf

[28] Meslek Hastalıklarımızı Neden Tanıyamıyoruz? Şimşek C. Erişim: 25 Haziran 2018, http://www.dergikaratahta.com/files/3/13.pdf

[29] Ozer A, Yakupogullari Y, Beytur A, et al. Risk factors of hepatitis B virus infection in Turkey: A population-based, case-control study: Risk Factors for HBV Infection. Hepatitis monthly. 2011;11(4):263.

[30] Türkiye Halk Sağlığı Kurumu. (2017). Türkiye'de Verem Savaşı 2016 Raporu. Erişim: 25 Haziran 2018, https://hsgm.saglik.gov.tr/ depo/haberler/verem-savas-raporu-2016-2017/Turkiyede Verem Savasi 2016 Raporu.pdf

[31] Fritschi L, Driscoll T. Cancer due to occupation in Australia. Australian and New Zealand journal of public health. 2006;30(3):213-9.

[32] Deschamps F, Barouh M, Deslee G, et al. Estimates of work-related cancers in workers exposed to carcinogens. Occupational Medicine. 2006;56(3):204-9.

[33] Espina C, Straif K, Friis S, et al. European Code against Cancer 4th Edition: Environment, occupation and cancer. Cancer Epidemiology. 2015; S84-92.

[34] Morrell S, Kerr C, Driscoll T, et al. Best estimate of the magnitude of mortality due to occupational exposure to hazardous substances. Occupational and Environmental Medicine 1998; 55:634-641.

[35] Rubinstein S, Wang C, Qu W. Occupational risk and chronic kidney disease: a population-based study in the United States adult population. International journal of nephrology and renovascular disease. 2013; 6:53. nephrology and renovascular disease. 2013; 6:53. 